\title{
Instructional Design: Skills to Benefit the Library Profession
}

\author{
Jennifer Turner
}

abstract: Librarians in many types of libraries frequently find themselves positioned as instructors in formal and informal educational settings. Librarians can help ensure that learner needs are better defined and addressed by gaining basic competency in instructional design (ID), an intentional process used to create effective, efficient educational and training programs. Additionally, instructional design skills have the potential to benefit librarians in nonteaching roles. This paper examines existing library literature to determine how librarians can benefit from ID skills and to identify core ID competencies for the profession, and suggests opportunities to investigate how librarians might best acquire these skills.

\section{Introduction}

$\mathrm{N}$ early all librarians provide some degree of instruction, whether it comes in the form of library instruction for undergraduate students, training sessions for fellow librarians and library technicians, or the development of online learning modules for remote library users. Despite the prevalence of teaching in library work, many librarians complete their master of library and information science degree (MLIS) or an equivalent degree without acquiring a good foundation in instructional design (ID).

This paper examines how librarians across library types and departments can benefit from instructional design proficiencies and argues that librarians should strive to attain core ID skills through formal or informal educational opportunities. It investigates ID theories discussed in library literature and compares the skills presented in the literature to a list of essential ID competencies for librarianship. This paper will investigate the following questions:

- How can librarians of all types benefit from knowledge of instructional design?

- What instructional design competencies should librarians consider as essential skills within their profession? 
This report will conclude with arguments in favor of including basic instructional design education in most, if not all, MLIS programs and will suggest how this might be accomplished.

\section{Librarians as Educators and Instructional Designers}

Multiple studies demonstrate librarian engagement with instruction in some form, regardless of library type. Instructional roles are usually correlated with academic and school librarians. However, a national survey of public librarians reports that 100

\section{Many librarians complete their mas- ter of library and information science degree (MLIS) or an equivalent de- gree without acquiring a good foun- dation in instructional design (ID).}

percent of city libraries offer formal or informal technology training, such as computer skills, photography, and website development classes. ${ }^{1}$ Reference librarians at nearly any library instruct patrons on how to use resources on a one-to-one or one-to-many basis. Circulation librarians teach visitors how to check out, renew, and return materials, and they show new circula-

tion technicians how to use the technology to perform these actions. Technical services librarians instruct technicians on how to use integrated library systems or how to catalog new resources. In addition to face-to-face teaching and training for the public or internal staff, many librarians create instruction modules such as handouts or online tutorials to assist patrons in accessing resources. Clearly, instructional roles for librarians are found across library and librarian categories. The use of instructional design concepts can help librarians design and implement effective educational experiences for their users.

Instructional design is a systematic process used to develop effective educational sessions and tools. ${ }^{2}$ Although there are multiple ID models, analyses by Purnima Valiathan demonstrate that each approach equips instructors to create lessons that meet defined and quantifiable learner needs. ${ }^{3}$ Instructional design enables its practitioners to extend their teaching beyond passive "sage on the stage," lecture-based instruction to create educational situations and materials that meet specified, measurable learning objectives.

To use instructional design methods effectively, teachers and trainers must become familiar with defined ID processes. The International Board of Standards for Training, Performance and Instruction, known as ibstpi, is a nonprofit group that develops, validates, and publishes ID standards for instructors, training managers, instructional designers, and evaluators. The group has identified 105 "performance statements" for instructional designers grouped under 22 broader "competencies." ${ }^{4}$ As ibstpi explains, even full-time instructional designers may not gain proficiency in each competency. This may be especially true for librarians and others who must juggle instructional design with responsibilities outside of their teaching roles. Steven Bell and John Shank agree, observing that librarians might not have time for thorough instructional design but might use elements of the process to improve library services. ${ }^{5}$ It is important for librarians to focus on the specific skills needed to succeed in their specialized teaching roles, not to attempt to become fully trained instructional designers. 


\section{Key ID Competencies for Librarians}

For librarians to gain proficiency in instructional design, it is important to identify which ID concepts are essential for them. The library literature often focuses on the use of specific ID models in planning library or information literacy instruction sessions. Bell and Shank, Char Booth, Valeda Dent Goodman, Troy Swanson, and other librarianauthors refer to the ADDIE model for instructional design. ${ }^{6}$ ADDIE guides practitioners through five stages of design:

1. Analysis, in which the practitioner defines learner needs.

2. Design, in which the practitioner identifies strategies to meet learner needs.

3. Development, in which the practitioner creates learning products, such as activities and materials.

4. Implementation, in which the practitioner or another qualified individual delivers products to learners.

5. Evaluation, in which the practitioner assesses the effectiveness of the learning products.

ADDIE may take more time and resources than many librarians can accommodate, so Bell and Shank introduced BLAAM — the Blended Librarians Adapted ADDIE Model. ${ }^{7}$ BLAAM streamlines ADDIE for academic librarians and encourages them to:

1. Assess learner needs through discussions with course instructors (assuming library instruction is part of a larger class, such as English Composition) and by informal assessments of student needs.

2. Create simple, measurable learning objectives.

3. Quickly develop instruction by drafting a simple plan and sharing it with a colleague or the course instructor for feedback.

4. Deliver the instruction and, as appropriate, provide training to other librarians teaching the lesson.

5. Measure the degree to which learning objectives were achieved to provide evidence of learning and to make enhancements to instruction.

The components of BLAAM and ADDIE may be used interchangeably, allowing librarians to customize the instructional design process to fit specific situations. ${ }^{8}$ An understanding of ADDIE, BLAAM, or other ID methods will assist any librarian in developing effective instruction tools or sessions, but these methods are only models and do not provide a full understanding of the ID process.

Valeda Dent Goodman reviews Myles I. Friedman and Steven P. Fisher's 1998 Handbook on Effective Instructional Strategies: Evidence for Decision-Making, which generalizes the components of instruction. Goodman recommends that librarians develop awareness of select instructional competencies. ${ }^{9}$ Of the 12 principles identified by Friedman and Fisher, Goodman highlights six as relevant to librarians in their instructional roles:

1. Surveying student readiness to identify whether students will be able to achieve the desired learning outcomes.

2. Defining instructional expectations to learners.

3. Providing contiguity to enable learners to make connections to the information and to ensure that evaluation relates to instruction. 
4. Using repetition to reinforce learning.

5. Providing transfer of learning between tasks, so that students take knowledge acquired in one situation and apply it to another. To do this effectively, the sequence of activities must be clear, so that students and their instructors understand which skills must be mastered before moving on to more complex tasks.

6. Using subject matter unifiers, such as outlines, hierarchical diagrams, and pictorial representations, to identify relationships within new information. ${ }^{10}$

Goodman's recommended principles do not reflect a specific instructional design method. Instead, they offer generalized guidance to librarians for the analysis and development portions of the ID process. However, Goodman's principles may not provide enough detail for librarians to practice these skills effectively. Goodman's list also ignores the need to evaluate instruction, as recommended in most ID approaches.

ADDIE, BLAAM, and Goodman's analysis of Farmer and Friedman's strategies offer starting points for thinking about instructional design, but ibstpi goes further. The group has identified an expansive list of principles for professional instructional designers, providing a much more detailed set of skills than those found in literature relating to specific models of instructional design. ${ }^{12}$ To identify which generalized skills stand out as essential, it is important to review the library literature about instructional design and the lists of professional competencies recommended by library organizations to create a set of key ID competencies for librarians.

The ibstpi publication Instructional Designer Competencies: The Standards sets out 105 performance statements grouped under 22 broader competencies. According to ibstpi,

\section{Librarians need to be selective in the ID skills they acquire be- cause they often must balance instructional roles with other elements of librarianship.}

the performance statements and competencies may be classified as "essential," meaning that all instructional designers should have that skill; "advanced," meaning that experienced instructional designers should have the skill; or "managerial," meaning that only managers of instructional design functions or teams require the skill. ${ }^{13}$ As previously noted, librarians need to be selective in the ID skills they acquire because they often must balance instructional roles with other elements of librarianship.

One starting place for identifying core instructional design skills for librarians is to compare the "essential" ID competencies and performance statements from the ibstpi list to the elements of instructional design commonly mentioned in library literature. A short version of ibstpi's "Instructional Design Competencies" is available online and can be downloaded free after registration. See the ibstpi website at http:/ / ibstpi.org/ instructional-design-competencies/.

Table 1 compares the "essential" ID competencies identified by ibstpi to the ADDIE and BLAAM instructional design models frequently cited in library literature and to the ID principles Goodman identifies as highly relevant to library instruction. ${ }^{14}$

Table 2 compares the six "essential" performance statements listed by ibstpi to those mentioned in the library literature. Only two of these performance statements are not covered by common librarian approaches to instructional design or by Goodman's 
Table 1.

\section{Instructional design competencies cited by ibstpi compared to those in library literature}

\begin{tabular}{|c|c|c|c|}
\hline ibstpi competency* & ADDIE & BLAAM $\dagger$ & $\begin{array}{l}\text { Valeda Dent } \\
\text { Goodman, } \\
\text { Keeping the } \\
\text { User in } \\
\text { Mind } \$\end{array}$ \\
\hline
\end{tabular}

Communicate effectively in visual, oral, and written form (p. 24)§

Update and improve knowledge, skills, and attitudes pertaining to instructional design and related fields (p. 25)

Identify and respond to ethical, legal, and political implications of design in the workplace (p. 25)

Identify and describe target population and environmental characteristics (p. 26)

Select and use analysis techniques for determining instructional content (p. 26)

Analyze the characteristics of existing and emerging technologies and their potential use (p. 27)

Use an instructional design and development process appropriate for a given project (p. 27)

Organize instructional programs and/or products to be designed, developed, and evaluated (p. 27)

Design instructional interventions (p. 27)

Select or modify existing instructional materials (p. 28)

Develop specifications that serve as the basis for media production (p. 28)

Revise instructional and noninstructional solutions based on data (p. 29) $\mathrm{x}$

X $\quad x-1$

$\mathrm{x}$

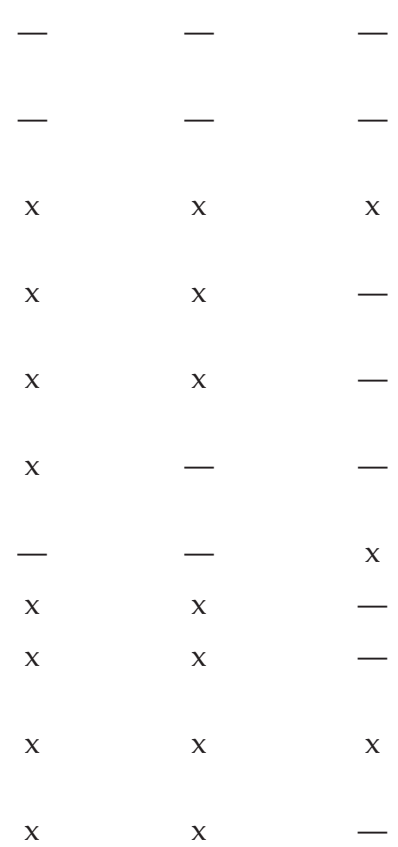

* Tiffany A. Koszalka, Darlene F. Russ-Eft, Robert A. Reiser, Fernando A. Senior Canela, Barbara Louise Hopkins Grabowski, and Clinton J. Wallington, Instructional Designer Competencies: The Standards, 4th ed. (Charlotte, NC: Information Age, 2013).

+Steven J. Bell and John D. Shank, Academic Librarianship by Design: A Blended Librarian's Guide to the Tools and Techniques (Chicago: American Library Association, 2007).

\# Valeda Dent Goodman, Keeping the User in Mind: Instructional Design and the Modern Library (Oxford, U.K.: Chandos, 2009), from Myles I. Friedman and Steven P. Fisher, Handbook on Effective Instructional Strategies: Evidence for Decision-Making (Columbia, SC: Institute for Evidence-Based Decision-Making in Education, 1998).

$\S$ The page numbers refer to Koszalka, Russ-Eft, Reiser, Senior Canela, Grabowski, and Wallington, Instructional Designer Competencies, 4th ed. 


\section{Table 2. \\ Instructional design performance standards identified by ibstpi compared to those in library literature}

ibstpi performance standard ${ }^{\star}$

ADDIE BLAAM $\dagger$ Valeda Dent

Goodman,

Keeping the

User in

Mind

Explain key concepts of instructional design (p. 24)§

Apply systems thinking to instructional design and performance improvement programs (p. 24)

Describe the nature of a learning or performance problem (p. 26)

Identify the learning processes and outcomes to be measured (p. 28)

Ensure that assessment is aligned with instructional goals, anticipated learning outcomes, and instructional strategies (p. 29)

Implement formative and summative evaluation plans (p. 29)

$\begin{array}{lll}- & - & - \\ - & - & - \\ x & x & x \\ x & x & x \\ x & x & \\ & & \\ x & x & -\end{array}$

${ }^{*}$ Not covered under an essential instructional design competency, as listed in Table 1; Tiffany A. Koszalka, Darlene F. Russ-Eft, Robert A. Reiser, Fernando A. Senior Canela, Barbara Louise Hopkins Grabowski, and Clinton J. Wallington, Instructional Designer Competencies: The Standards, 4th ed. (Charlotte, NC: Information Age, 2013).

+ Steven J. Bell and John D. Shank, Academic Librarianship by Design: A Blended Librarian's Guide to the Tools and Techniques (Chicago: American Library Association, 2007).

₹ Valeda Dent Goodman, Keeping the User in Mind: Instructional Design and the Modern Library (Oxford, U.K.: Chandos, 2009), from Myles I. Friedman and Steven P. Fisher, Handbook on Effective Instructional Strategies: Evidence for Decision-Making (Columbia, SC: Institute for Evidence-Based Decision-Making in Education, 1998).

$\S$ The page numbers refer to Koszalka, Russ-Eft, Reiser, Senior Canela, Grabowski, and Wallington, Instructional Designer Competencies, 4th ed. 
identification of ID principles relevant to library instruction. The two missing performance statements, "Explain key concepts of instructional design" and "Apply systems thinking to instructional design and performance improvement programs," may fall outside a librarian's role. ${ }^{15}$ However, the other "essential" aptitudes are well suited to library uses of instructional design.

For the most part, ibstpi's list of "essential" instructional design skills correlates with ID components recommended for librarians by the literature. The literature about instructional design omits, however, the competencies advising designers to (1) update and improve knowledge, skills, and attitudes pertaining to instructional design and related fields and (2) identify and respond to ethical, legal, and political implications of design in the workplace. ${ }^{16}$ Nevertheless, lists of recommended professional com-

\section{A review of professional standards for all librarians and for librarians in spe- cific roles within the discipline provides further encouragement for librarians to become skilled in ibstpi's "essential" instructional design competencies.} petencies for librarians encourage members of the profession to be proficient in related areas. In fact, a review of professional standards for all librarians and for librarians in specific roles within the discipline provides further encouragement for librarians to become skilled in ibstpi's "essential" instructional design competencies.

Table 3 identifies how ibstpi's "essential” ID competencies performance statements compare to the core competencies recommended by library organizations, such as those for special librarians, music librarians, research librarians, and reference and user services librarians. ${ }^{17}$ The Association of College and Research Libraries document "Standards for Proficiencies for Instruction Librarians and Coordinators" includes a section dedicated to instructional design, and all the competency sets from library groups contain elements relating to ID. In fact, only two of the 18 ibstpi "essential" skills, "Explain key concepts of instructional design" and "Apply systems thinking to instructional design and performance improvement programs," remain outside suggested librarian competencies.

Given the literature's support of librarians as educators, it is not surprising to find elements of instructional design mentioned in competency sets for librarians. Beyond formal and informal library training and instruction, Troy Swanson points out that planning and assessment-two basic concepts of instructional design-have applications across librarianship. ${ }^{18}$ As Swanson argues, instructional design may be applied to develop a user-centric approach to libraries by giving librarians a framework for developing clear understandings of user needs for services, space, instruction, and more. ${ }^{19}$ As user experience and assessment grow in importance, knowledge of instructional design will assist librarians in analyzing user needs, developing and designing facilities and services to meet those needs, implementing services for maximum impact, and assessing the effectiveness of their offerings. 


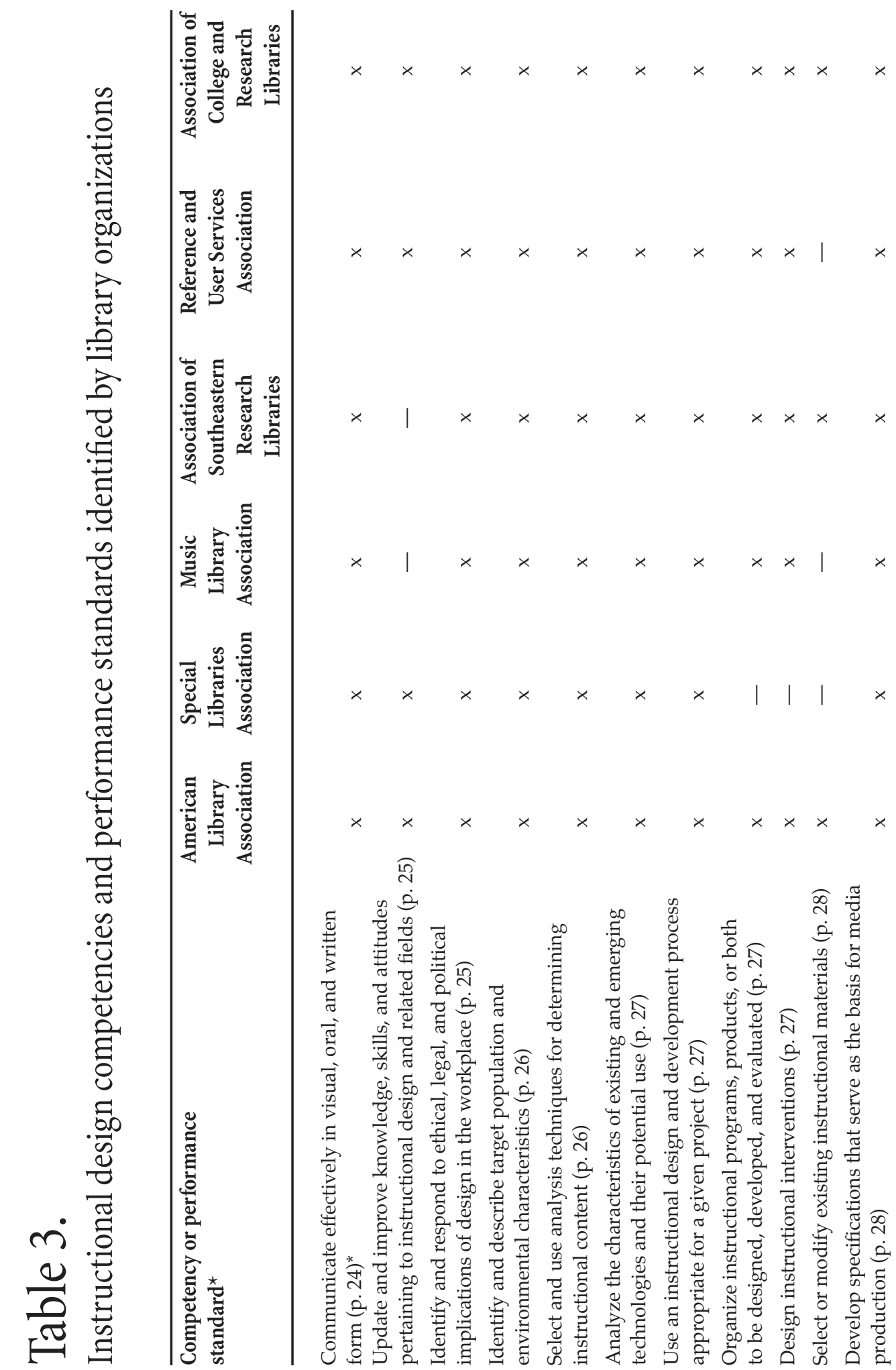




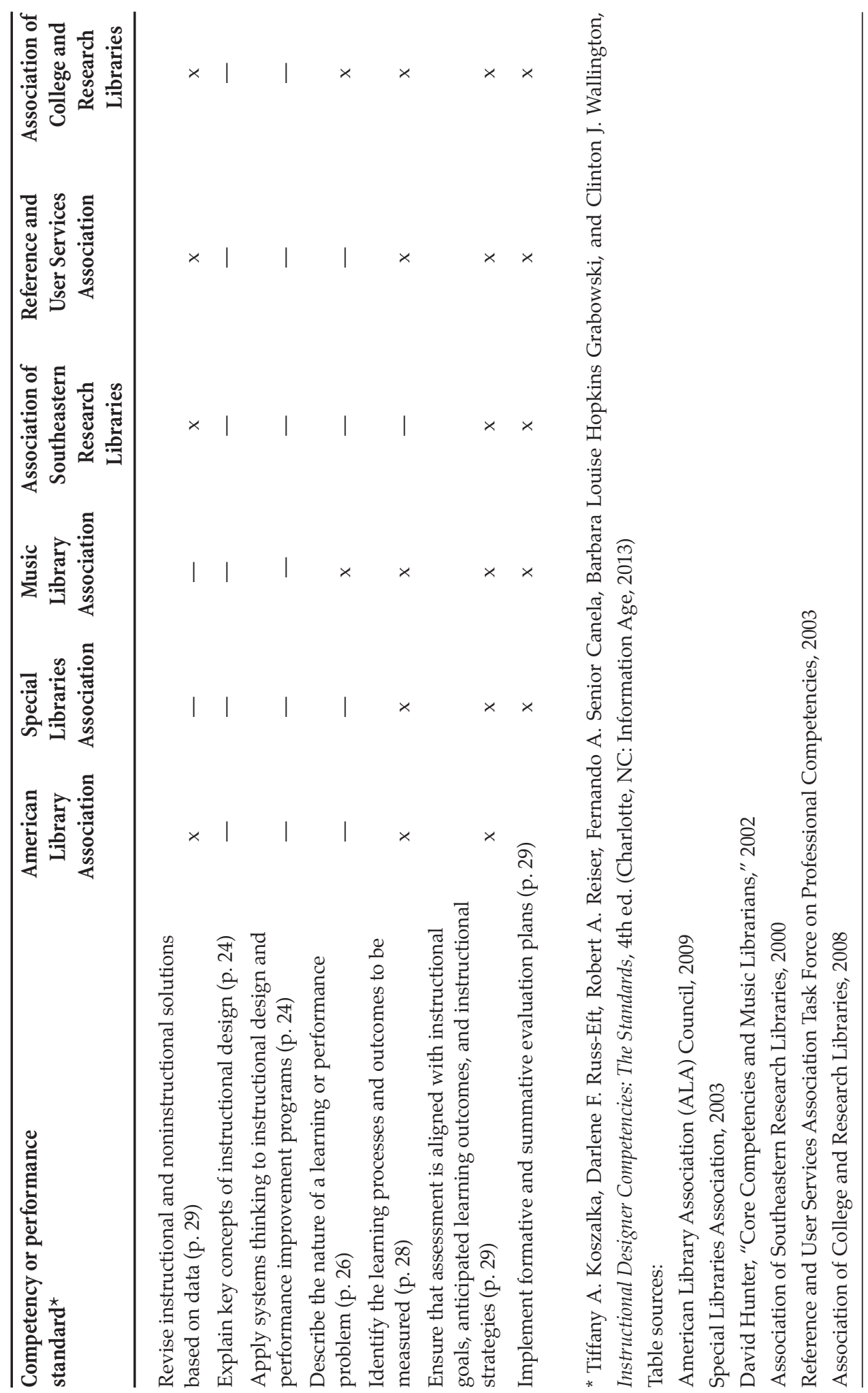




\section{Librarian Education in Instructional Design}

Despite the prevalence of instruction in librarian positions and the importance and applicability of ID skills for all librarians, Jenny Bronstein notes a number of studies indicating that librarians lack confidence in their ability to educate. ${ }^{20}$ This insecurity may result from Farmer's finding that while "instruction has become a core function for most librarians ... academic preparation of librarians does not always include the principles of instruction, especially that of instructional design." ${ }^{21}$ This is unfortunate. As Bell and Shank observe, embracing the librarian's role in teaching and learning is an opportunity to transform the profession and to maintain relevance in the face of new search technologies that may marginalize it. ${ }^{22}$ However, librarians may hesitate to undertake instructional roles and to apply ID techniques if they lack the firm foundation in educational skills, including the components of instructional design, that would promote confidence. These observations indicate a gap in the education of future librarians. Becoming effective educators by developing ID skills will improve librarians' ability to move the profession into the future.

The Standards for Accreditation of Master's Programs in Library and Information Studies (MLIS) of the Council of the American Library Association (ALA) requires MLIS programs to prepare librarians to be effective and productive members of their profes-

A firm grounding in instructional design will assist librarians in creating learning materials and instruction sessions that enable library patrons to access and use information effectively. sions. ${ }^{23}$ However, because librarianship is diverse and the standards are suggestive rather than prescriptive, accredited programs are not required to provide specific courses or to address specific student learning outcomes. The ALA says, however, that these programs must include coursework that "encompasses infor-

mation and knowledge creation, communication ... organization and description ... [and] dissemination." ${ }^{24}$ A firm grounding in instructional design will assist librarians in creating learning materials and instruction sessions that enable library patrons to access and use information effectively.

In addition to preparing students to create, organize, describe, and disseminate information, masters programs accredited by the ALA are required to ensure that their graduates meet core competencies for the profession. These core competencies often align with instructional design, as demonstrated in Table 3. Further, the ALA standards dictate that an MLIS curriculum should provide "the opportunity for students to construct coherent programs of study that allow individual needs, goals, and aspirations to be met... and that will foster development of the competencies necessary for productive careers." ${ }^{25}$ Instructional design work will allow students to gain the skills they need to be effective instructors. Finally, the standards for accreditation advocate for innovative and forward-thinking programs of study. The accreditation standards, while not explicitly calling for ID coursework, certainly support its inclusion in MLIS curricula.

ALA-accredited programs have increasingly included formal courses in instruction. Loyd Mbabu reports that most library and information science curricula now offer a series 
of classes in instruction, ${ }^{26}$ which likely cover instructional design. However, as Heidi Julien notes, few master's programs require these courses as part of the core curriculum. ${ }^{27}$ While librarians interested in careers in academic librarianship may take these courses, many soon-to-be librarians lack the opportunity or interest to take such classes. This means many librarians may begin their professional careers with little or no knowledge of the ID process. Indeed, Leslee Shell, Steven Crawford, and Patricia Harris note that librarians do not necessarily understand instructional design upon entry to the field and may have knowledge gaps that impair their ability to design effective instruction. ${ }^{28}$ As the comparison of ibstpi competencies to core competencies for librarians in Table 3 suggests, and as Swanson argues, ID has applications beyond traditional teaching. ${ }^{29}$ The same knowledge gaps that impair a librarian's ability to design effective instruction may also hinder the ability to create effective services and spaces.

If librarians complete their formal educations without receiving an introduction to instructional design, library instruction—and library services in general—may suffer. When librarians do become aware of the utility of instructional design, they must seek professional development opportunities or rely on outside resources to gain a background in instructional design. If resources allow, librarians may collaborate with ID specialists at academic institutions or engage in professional development to learn instructional design for

Ensuring that core competencies for instructional design are included in core MLIS curricula, not just as elective courses, would help ensure that all librarians graduate with a basic knowledge of this important skill set. themselves. However, for librarians with limited resources, it may not be possible to collaborate with instructional designers or to learn about ID through professional development opportunities. Ensuring that core competencies for instructional design are included in core MLIS curricula, not just as elective courses, would help ensure that all librarians graduate with a basic knowledge of this important skill set.

\section{Conclusion}

Librarians' educational roles in a variety of professional settings support their acquisition of core instructional design concepts. A review of existing literature about librarians and instructional design shows that ibstpi's "essential" ID proficiencies are well suited for librarians. Additionally, a review of core competencies identified by various library organizations demonstrates how ibstpi's "essential" proficiencies align well with the professional skills librarians are expected to possess.

However, MLIS education generally does not require future librarians to take courses that introduce core concepts of instructional design. While the ALA may not require that all MLIS students take instruction classes, it might look at how ID concepts could be integrated into core curricula. Future studies could investigate which ID competencies are currently present in MLIS curricula and in which classes these skills are introduced. Researchers might also explore how skills might be embedded in core classes to ensure that the majority of graduates have some proficiency in instructional design. If elements 
of instructional design are already taught in core classes not clearly labeled as "instruction," studies might look at how students could be encouraged to identify how these elements combine to create the ID process. Perhaps students of library science are already learning instructional design but need assistance synthesizing concepts in ways that give them the confidence that they have the skills to develop, deliver, and assess instruction.

Instructional design is a powerful tool for creating educational programs to meet real learner needs. Beyond instruction, elements of instructional design have applications for planning and assessing all library services. It is time to empower librarians to create services to meet the real needs of patrons or library users by encouraging them to develop ID competencies.

Jennifer Turner is the instructional services librarian at Minnesota State University, Mankato; she may be reached by e-mail at: jennifer.turner@mnsu.edu.

\section{Notes}

1. John Carlo Bertot, Paul T. Jaeger, Jean Lee, Kristofer Dubbels, Abigail J. McDermott, and Brian Real, 2013 Digital Inclusion Survey: Survey Findings and Results Executive Summary (College Park: University of Maryland College Park, College of Information Studies, Information Policy \& Access Center, 2014), 10, accessed February 6, 2015, http:/ / digitalinclusion.umd.edu/sites / default/ files / uploads / 2013DigitalInclusionExecutiveSum mary.pdf.

2. Lesley S. J. Farmer, Instructional Design for Librarians and Information Professionals (New York: Neal-Schuman, 2011); Valeda Dent Goodman, Keeping the User in Mind: Instructional Design and the Modern Library (Oxford, U.K.: Chandos, 2009); George M. Piskurich, Rapid Instructional Design: Learning ID Fast and Right (San Francisco: Pfeiffer, 2006).

3. Purnima Valiathan, "Instructional Design," Training Journal, March 2010, 74; Purnima Valiathan, "Instructional Design," Training Journal, February 2010, 76; Purnima Valiathan, "Instructional Design," Training Journal, January 2010, 74.

4. Tiffany A. Koszalka, Darlene F. Russ-Eft, Robert A. Reiser, Fernando A. Senior Canela, Barbara Louise Hopkins Grabowski, and Clinton J. Wallington, Instructional Designer Competencies: The Standards, 4th ed. (Charlotte, NC: Information Age, 2013).

5. Steven J. Bell and John D. Shank, Academic Librarianship by Design: A Blended Librarian's Guide to the Tools and Techniques (Chicago: American Library Association [ALA], 2007).

6. Bell and Shank, Academic Librarianship by Design; Char Booth, Reflective Teaching, Effective Learning: Instructional Literacy for Library Educators (Chicago: ALA, 2011); Goodman, Keeping the User in Mind; Troy A. Swanson, "ADDIE [Analyze, Design, Develop, Implement, and Evaluate] in the Library: Building a Model for the Information Age Library," Community $\mathcal{E}$ Junior College Libraries 13, 2 (2005): 51-61.

7. Bell and Shank, Academic Librarianship by Design.

8. Ibid., 55-58.

9. Goodman, Keeping the User in Mind.

10. Ibid., 106-10.

11. Ibid.

12. Koszalka, Russ-Eft, Reiser, Senior Canela, Grabowski, and Wallington, Instructional Designer Competencies.

13. Ibid.

14. Goodman, Keeping the User in Mind.

15. Koszalka, Russ-Eft, Reiser, Senior Canela, Grabowski, and Wallington, Instructional Designer Competencies, 24. 
16. Ibid., 25.

17. For the purposes of this paper, competencies recommended only for instruction coordinators are excluded from analysis because instruction coordinators are a specific subset of instruction librarians.

18. Swanson, "ADDIE in the Library."

19. Ibid.

20. Jenny Bronstein, "The Role and Work Perceptions of Academic Reference Librarians: A Qualitative Inquiry," portal: Libraries and the Academy 11, 3 (2011): 791-811.

21. Farmer, Instructional Design for Librarians and Information Professionals, xiv.

22. Bell and Shank, Academic Librarianship by Design.

23. Council of the American Library Association, Standards for Accreditation of Master's Programs in Library \& Information Studies (Chicago: ALA, 2008), accessed February 6, 2015, http:/ / www.ala.org/accreditedprograms/ sites/ala.org.accreditedprograms/files / content/standards/standards_2008.pdf.

24. Ibid., 3 .

25. Ibid., 8 .

26. Loyd G. Mbabu, "LIS Curricula Introducing Information Literacy Courses alongside Instructional Classes," Journal of Education for Library and Information Science 50, 3 (2009): 203-10.

27. Heidi Julien, "Education for Information Literacy Instruction: A Global Perspective," Journal of Education for Library and Information Science 46, 3 (2005): 210-16.

28. Leslee Shell, Steven Crawford, and Patricia Harris, "Aided and Embedded: The Team Approach to Instructional Design," Journal of Library \& Information Services in Distance Learning 7, 1-2 (2013): 143-55.

29. Swanson, "ADDIE in the Library." 